\title{
Protective immunity in rainbow trout Oncorhynchus mykiss following immunization with distinct molecular mass fractions isolated from Flavobacterium psychrophilum
}

\author{
Benjamin R. LaFrentz ${ }^{1}$, Scott E. LaPatra ${ }^{2}$, Gerald R. Jones ${ }^{2}$, Kenneth D. Cain ${ }^{1, *}$ \\ ${ }^{1}$ Department of Fish and Wildlife Resources and the Aquaculture Research Institute, University of Idaho, Moscow, \\ Idaho 83844-1136, USA \\ ${ }^{2}$ Clear Springs Foods, Research Division, PO Box 712, Buhl, Idaho 83316, USA
}

\begin{abstract}
Vaccine development for coldwater disease (CWD), also known as rainbow trout fry syndrome (RTFS), has been based primarily on whole-cell bacterins or outer membrane fractions of Flavobacterium psychrophilum. In the present study, immunogenic regions of the bacterium corresponding to $18-28,41-49$, and $70-100 \mathrm{kDa}$ were identified by western blot analysis using rainbow trout Oncorhynchus mykiss immune sera. Following sodium dodecyl sulfate-polyacrylamide gel electrophoresis (SDS-PAGE), antigens within these regions were isolated by electro-elution and used in immunization trials. Groups of rainbow trout fry were immunized with these regions emulsified with Freund's complete adjuvant (FCA) and a formalin-killed bacterin emulsified with FCA. It was demonstrated that the 70-100 and 41-49 kDa regions and F. psychrophilum treatments elicited significant protection when compared to the saline control following subcutaneous challenge with 2 doses of a virulent strain of F. psychrophilum. Immunization with the 70-100 kDa region resulted in near complete protection in fish with mean cumulative percent mortality (CPM) of $6 \%$ and mean relative percent survival (RPS) of $94 \%$ at the lower challenge dose $\left(6.25 \times 10^{6}\right.$ colony forming units $\mathrm{fish}^{-1}$ ). This preparation also stimulated a high level of specific antibody to $F$. psychrophilum, as detected by an enzyme-linked immunosorbent assay (ELISA). Western blot analysis using sera from fish immunized with the $70-100 \mathrm{kDa}$ region demonstrated that high molecular weight proteins and the O-polysaccharide component of lipopolysaccharide (LPS) are recognized by serum antibodies. This suggests that these antigens may be involved in eliciting a highly protective immune response, and could serve as vaccine candidates.
\end{abstract}

KEY WORDS: Flavobacterium psychrophilum • Coldwater disease · Antibody-mediated protection · Lipopolysaccharide

\section{INTRODUCTION}

Coldwater disease (CWD), also referred to as rainbow trout fry syndrome (RTFS), is a worldwide problem in salmonid aquaculture. The causative agent, Flavobacterium psychrophilum, is a Gramnegative bacterium capable of causing an acute septicemic infection in salmonids (Wood \& Yasutake 1956) and a few other fish species (Lehmann et al.
1991). This pathogen often causes large economic losses associated with mortality and spinal deformities, and is considered one of the most significant pathogens in freshwater salmonid aquaculture worldwide (Michel et al. 1999). In the Idaho rainbow trout Oncorhynchus mykiss industry, most losses due to CWD typically occur when fish are 2 to $4 \mathrm{~g}$ in weight, and mortality may also occur as a dual infection with infectious hematopoietic necrosis virus (IHNV) in fish 
weighing 10 to $20 \mathrm{~g}$. In this situation, vaccination of fish may be possible. However, disease prevention at early life-stages associated with RTFS may be more difficult.

Currently there is no commercial vaccine available against Flavobacterium psychrophilum. Various levels of protection have been demonstrated in immunization trials with whole-cell bacterins administered by immersion and injection routes. Direct immersion of coho salmon Oncorhynchus kisutch into killed cells resulted in protection (Holt 1987); however, no protection was demonstrated by immersion in rainbow trout (LaFrentz et al. 2002). High levels of protection have been achieved by immunizing coho salmon and rainbow trout intraperitoneally (ip) with whole-cells emulsified with Freund's complete adjuvant (FCA) (Holt 1987, LaFrentz et al. 2002). However, ip injection of rainbow trout with killed bacteria without an adjuvant has resulted in only minimal protection (Obach \& Laurencin 1991, LaFrentz et al. 2002, Rahman et al. 2002).

Since immunization with whole-cell bacteria without adjuvant incorporation has resulted in minimal protection, recent studies have been aimed at identifying vaccine target antigens. Rahman et al. (2002) tested a vaccine preparation in rainbow trout consisting of the outer membrane fraction of Flavobacterium psychrophilum in order to enhance antigenicity. This preparation resulted in a high relative percent survival (RPS) that was significantly greater than in fish immunized with a formalin-killed bacterin. These authors suggested that the increased protection was due to the outer membrane proteins and lipopolysaccharides (LPS) that were present. Additionally, Crump et al. (2001) identified several immunogenic protein and LPS antigens of F. psychrophilum, and Merle et al. (2003) identified a membrane glycoprotein (P60). However, the role these antigens play in eliciting a protective immune response is still unknown.

In the present study, our goal was to further characterize the immunogenic components of Flavobacterium psychrophilum in order to enhance vaccine development. The objectives were to: (1) identify antigens recognized in a western blot by serum antibodies from immunized rainbow trout, (2) elute antigens within immunogenic regions from gels following electrophoresis, and (3) evaluate the role antigens within these regions play in eliciting a protective immune response in rainbow trout.

\section{MATERIALS AND METHODS}

Bacterial culture. A virulent strain of Flavobacterium psychrophilum (259-93) was used for electrophoresis, western blot analysis, enzyme-linked immunosorbent assay (ELISA) testing, immunization trials and pathogen challenges. The isolate was cultured in tryptone yeast extract salts (TYES) broth (Holt et al. 1993) or agar at $15^{\circ} \mathrm{C}$ for $72 \mathrm{~h}$. Bacteria were harvested from broth by centrifugation for $15 \mathrm{~min}$ at $4300 \times g$. The number of colony forming units $(\mathrm{cfu}) \mathrm{ml}^{-1}$ was determined by plating 10 -fold serial dilutions on TYES agar plates.

Bacteria used for electrophoresis and western blot analysis were resuspended in phosphate buffered saline (PBS) to optical densities (OD) of 2.0 and 0.8 at $525 \mathrm{~nm}$ following centrifugation. These bacterial suspensions were aliquoted into $1.5 \mathrm{ml}$ microcentrifuge tubes and frozen at $-20^{\circ} \mathrm{C}$ until needed for analysis. Whole-cell lysates were digested with proteinase $\mathrm{K}$ (Sigma) according to the method of Hitchcock \& Brown (1983), with some modification. Briefly, $1.4 \mathrm{ml}$ aliquots of Flavobacterium psychrophilum at an OD of 0.8 were centrifuged at $5000 \times g$ for $5 \mathrm{~min}$ and the supernatant was removed. The pellets were resuspended in $50 \mu \mathrm{l}$ sample buffer (Laemmli 1970) with $40 \mathrm{mM}$ dithiothreitol (DTT) substituted for 2-mercaptoethanol and boiled for $10 \mathrm{~min}$. The cell lysates were then digested with $25 \mu \mathrm{g}$ proteinase $\mathrm{K}$ dissolved in $10 \mu \mathrm{l}$ sample buffer, mixed thoroughly and incubated for $1 \mathrm{~h}$ at $60^{\circ} \mathrm{C}$. The digested bacteria were frozen at $-80^{\circ} \mathrm{C}$ until needed for analysis.

For immunization trials, Flavobacterium psychrophilum broth cultures were killed by adding $1 \%$ formalin and incubated overnight on a stir plate at $15^{\circ} \mathrm{C}$. To confirm the bacteria were non-viable, samples were plated on TYES agar, incubated at $15^{\circ} \mathrm{C}$ for $72 \mathrm{~h}$, and analyzed for growth. Killed F. psychrophilum cells were harvested by centrifugation for $15 \mathrm{~min}$ at $4300 \times$ $g$ and resuspended in $0.85 \%$ saline as a stock solution. The stock bacterial solution was stored at $4{ }^{\circ} \mathrm{C}$ for $24 \mathrm{~h}$ prior to immunization.

Flavobacterium psychrophilum used for challenge trials were grown on TYES agar. Bacteria were harvested with sterile cotton-tip applicator sticks and resuspended in $0.85 \%$ saline to an OD of 0.6 at $525 \mathrm{~nm}$, which corresponds to approximately $2.5 \times 10^{9} \mathrm{cfu} \mathrm{ml}^{-1}$. This inoculum was diluted 1:10 in saline for an additional challenge dose.

Sodium dodecyl sulfate-polyacrylamide gel electrophoresis (SDS-PAGE). SDS-PAGE was carried out according to the method of Laemmli (1970) with some modifications. Whole-cell lysates were separated using pre-cast 10 to $20 \%$ polyacrylamide gradient gels with a $4 \%$ stacking gel (Bio-Rad). Prior to electrophoresis, whole-cell lysates (OD of 2.0) were diluted 1:2 in sample buffer (Laemmli 1970) without a reducing agent (DTT) and boiled for $4 \mathrm{~min}$. Gels were electrophoresed using a Mini-PROTEAN 3 electrophoresis cell (BioRad) for $15 \mathrm{~min}$ at $90 \mathrm{~V}$ constant, then for approxi- 
mately $90 \mathrm{~min}$ at $120 \mathrm{~V}$ constant. Proteinase-Kdigested cells were diluted 1:2 in sample buffer (Laemmli 1970) containing $40 \mathrm{mM}$ DTT and separated using pre-cast $12 \%$ resolving gel with a $4 \%$ stacking gel (Bio-Rad). Gels were electrophoresed at $100 \mathrm{~V}$ constant using a Mini-PROTEAN 3 electrophoresis cell (Bio-Rad). Molecular mass of antigens was estimated according to the apparent molecular weights of protein standards. Proteinase-K-digested Flavobacterium psychrophilum cells were silver-stained according to the method of Hitchcock \& Brown (1983) to visualize LPS components.

Western blot analysis. Western blot analysis was performed using immune sera to identify immunogenic regions to test as vaccine candidate antigens. Different pools of immune sera were obtained from juvenile rainbow trout immunized with whole-cell Flavobacterium psychrophilum with or without FCA (LaFrentz et al. 2002). This analysis was also utilized to identify specific antigens recognized by serum antibodies from fish immunized with the immunogenic regions. Following SDS-PAGE of whole-cell lysates and proteinase-K digested cells, antigens in the gels were transferred onto nitrocellulose membranes by electrophoresis at a constant $100 \mathrm{~V}$ for $1 \mathrm{~h}$ in a Mini Trans-blot electrophoretic transfer cell (Bio-Rad), as described by Towbin et al. (1979). The nitrocellulose membranes were blocked for $1 \mathrm{~h}$ at room temperature in PBS containing $4 \%$ non-fat dry milk. Immunodetection was performed by overnight incubation at $15^{\circ} \mathrm{C}$ using rainbow trout antiserum to $F$. psychrophilum diluted 1:50 in PBS containing 0.05\% tween-20, $0.05 \%$ sodium azide, and $4 \%$ non-fat dry milk (PBST-AZNFDM). The primary fish antibody was detected by incubation of membranes for $1 \mathrm{~h}$ at room temperature with a monoclonal mouse antibody raised against trout immunoglobulin (mAb 1.14, DeLuca et al. 1983) diluted 1:40 in PBS containing 0.05\% Tween-20 and $0.05 \%$ sodium azide (PBST-AZ). Membranes were then incubated for $1 \mathrm{~h}$ at room temperature with an alkaline-phosphatase conjugated goat anti-mouse immunoglobulin (Bio-Rad) diluted 1:500 in PBST-AZ. Between each incubation, the membranes were washed 3 times in PBST-AZ. The immunoreactive bands were visualized using 5-bromo-4-chloro-3indolylphosphate toluidine salt and 4-nitro blue tetrazolium chloride (Bio-Rad).

Antigen isolation and elution. Immunogenic regions, identified by western blot analysis using immune sera from immunized juvenile rainbow trout, were isolated by SDS-PAGE of whole-cell Flavobacterium psychrophilum lysates using a Mini-PROTEAN Dodeca Cell (Bio-Rad). Approximately 70 pre-cast 10 to $20 \%$ gradient gels (Bio-Rad) containing a $450 \mu \mathrm{l}$ prep-well were electrophoresed as previously de- scribed. Immunogenic regions were cut from gels using prestained standards as a basis for excision. The gel slices were stored at $-80^{\circ} \mathrm{C}$ until needed for electro-elution.

Antigens were eluted from gel slices using a model 422 electro-eluter (Bio-Rad) according to manufacturer's instructions. Briefly, gel slices were cut into small pieces, loaded into the apparatus and electrophoresed for $5 \mathrm{~h}$ at $60 \mathrm{~mA}$. Antigen was harvested and stored at $-20^{\circ} \mathrm{C}$ until dialysis could be performed. Antigen samples were loaded into $12 \mathrm{kDa}$ molecular weight cut-off dialysis tubing (Sigma) and dialysed overnight in distilled water at room temperature. Following dialysis, the antigens were concentrated using a speed-vac (CentriVap Concentrator). The protein concentration of eluted antigens was determined using a Micro BCA protein assay (Pierce). Antigen samples were then diluted to $800 \mu \mathrm{g}$ protein $\mathrm{ml}^{-1}$ with sterilized distilled water and stored at $-80^{\circ} \mathrm{C}$ until needed for immunizations. SDS-PAGE was performed on the eluted antigen samples as described above for wholecell lysates, and elution efficiency was determined by rapid silver-staining (Ausubel et al. 1999).

Fish and rearing conditions. Rainbow trout (mean weight, $2.8 \mathrm{~g}$ ) were used for the immunization trial (Clear Springs Foods strain rainbow trout). Fish were maintained in 378 l tanks supplied with specificpathogen-free $15^{\circ} \mathrm{C}$ spring water treated with ultraviolet light. A portion of these fish was transferred to $19 \mathrm{l}$ tanks for use in challenge studies. Fish were maintained by feeding $1 \%$ body weight per day of a pelleted trout feed (Clear Springs Foods).

Vaccine preparation. The formalin-killed bacterin was prepared by suspending killed bacteria in $0.85 \%$ saline to an optical density of 0.8 at $525 \mathrm{~nm}$, which corresponds to approximately $7 \times 10^{9} \mathrm{cfu} \mathrm{ml}^{-1}$. This inoculum was centrifuged for $15 \mathrm{~min}$ at $4300 \times g$, the supernatant removed, and the cells resuspended in saline to one-half of the original volume. The vaccine treatment was prepared by adding an equal volume of FCA (Sigma) and forcing both solutions through 2 connected syringes until fully emulsified. Treatments corresponding to each eluted immunogenic region were prepared by combining $2.5 \mathrm{ml}$ of each preparation (800 $\mu \mathrm{g}$ protein $\mathrm{ml}^{-1}$ ) with an equal volume of FCA by forcing both solutions through 2 connected syringes until fully emulsified. The final concentration of protein for each of these vaccine preparations was approximately $400 \mu \mathrm{g}$ protein $\mathrm{ml}^{-1}$.

The control preparations used were $0.85 \%$ saline and saline emulsified with FCA. The saline/FCA control was prepared by combining saline with an equal volume of FCA as described above.

Fish immunization. Rainbow trout were anaesthetized by immersion in approximately $50 \mathrm{mg} \mathrm{l}^{-1}$ tri- 
caine methane sulfonate (MS-222, Argent) before immunization. Approximately 160 rainbow trout per treatment were immunized by ip injection (25-gauge needle) with $25 \mu \mathrm{l}$ volume containing formalin-killed cells $\left(1.8 \times 10^{8} \mathrm{cfu} \mathrm{fish}^{-1}\right)$ with FCA, $10 \mu \mathrm{g} 18-28 \mathrm{kDa}$ antigens with FCA, $10 \mu \mathrm{g}$ 41-49 kDa antigens with FCA, and 10 $\mu \mathrm{g} 70-100 \mathrm{kDa}$ antigens with FCA. Control fish (160 rainbow trout control ${ }^{-1}$ ) were injected ip with $25 \mu \mathrm{l}$ of $0.85 \%$ saline with or without FCA.

Prior to immunization, rainbow trout were bled and sera harvested for use as negative controls in the western blot and ELISA analyses. Two pools of 5 randomly selected fish were bled by severing the caudal peduncle and collecting blood in $0.1 \mathrm{ml}$ hematocrit tubes. Blood was placed in $1.5 \mathrm{ml}$ microcentrifuge tubes and allowed to clot overnight at $4^{\circ} \mathrm{C}$. Serum was collected following centrifugation at $15000 \times g$ for $5 \mathrm{~min}$. Sera samples were stored at $-20^{\circ} \mathrm{C}$ until needed for analysis.

ELISA. An ELISA was performed using sera samples obtained from treatment groups prior to and following immunization to identify anti-Flavobacterium psychrophilum antibodies. The assay was performed as described by LaFrentz et al. (2002). The ELISA titer was defined as the reciprocal of the highest dilution showing an OD at least 2 times greater than the negative control. The negative control serum was the pool of equal volumes of sera from 25 -fish pools taken from study fish prior to immunization (see above).

Bacterial challenge. At $10 \mathrm{wk}$ post-immunization, rainbow trout averaged $7.5 \mathrm{~g}$ in weight and were challenged with live Flavobacterium psychrophilum cells by subcutaneous injection at the dorsal midline just posterior to the dorsal fin with a 30-gauge needle. Duplicate groups of 25 fish treatment ${ }^{-1}$ were challenged with $25 \mu \mathrm{l}$ of live F. psychrophilum suspended in saline to an OD of 0.6 and a lower dose consisting of a 1:10 dilution of this inoculum. These doses corresponded to approximate concentrations of $6.25 \times 10^{7}$ and $6.25 \times 10^{6} \mathrm{cfu} \mathrm{fish}^{-1}$, respectively. Mock-infected controls (25 fish treatment ${ }^{-1}$ ) were injected with $25 \mu \mathrm{l}$ of $0.85 \%$ saline.

Mortalities were recorded daily for $28 \mathrm{~d}$ and a minimum of $20 \%$ of the daily mortalities were re-examined for Flavobacterium psychrophilum by inoculating spleen tissue onto TYES agar. The cumulative percent mortality (CPM) and RPS of all replicates were calculated. The RPS was calculated using the following equation:

RPS $=\left(1-\frac{(\text { CPM of vaccinated group })}{(\text { CPM of unvaccinated control group })}\right) \times 100$

Prior to bacterial challenge, rainbow trout were bled for western blot and ELISA analysis. Five pools of 3 randomly selected fish were bled and serum harvested for all treatments as previously described. Sera samples were stored at $-20^{\circ} \mathrm{C}$ until needed for analysis.

Statistical analysis. Mean cumulative percent mortality following bacterial challenge was analyzed by 1 way ANOVA and pairwise comparisons were made using Tukey's test (GraphPad Prism, GraphPad Software). An analysis of serum ELISA antibody titers between treatment groups was performed by ANOVA on $\log _{10}$-transformed titer data and pairwise comparisons were made using Tukey's test. Differences were considered significant at $\mathrm{p}$-values $<0.05$.

\section{RESULTS}

\section{Western blot analysis using immune serum}

To identify immunogenic components, western blot analysis was performed with whole-cell lysates using immune sera obtained from rainbow trout previously immunized with formalin-killed Flavobacterium psychrophilum preparations with or without FCA. An immunogenic region with an apparent molecular mass of approximately $70-100 \mathrm{kDa}$ was identified, as well as regions with apparent molecular masses of approximately 41-49 and 18-28 kDa (Fig. 1). Antigens within these immunogenic regions were isolated for immunization trials. The process of isolating the antigens was efficient; however, slightly different regions were

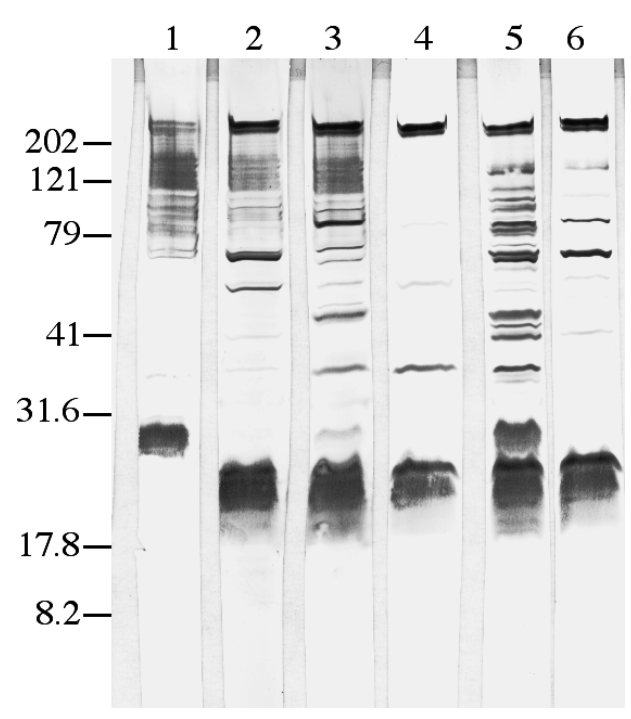

Fig. 1. Flavobacterium psychrophilum. Western blot analysis of whole-cell F. psychrophilum (259-93) lysates using different pools of juvenile Oncorhynchus mykiss sera obtained following intraperitoneal immunization with formalin-killed $F$. psychrophilum emulsified with (Lanes 1 to 3) or without (Lanes 4 to 6) FCA. Molecular mass markers (kDa) are indicated on the left 


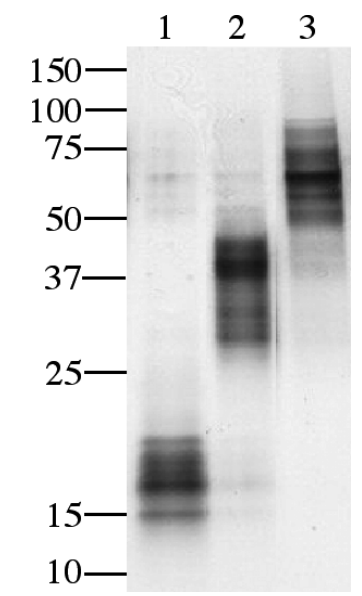

Fig. 2. Flavobacterium psychrophilum. Polyacrylamide gel silver-stained to visualize the isolated immunogenic regions of $F$. psychrophilum (259-93) following SDS-PAGE. Lane 1: 18-28 kDa region; Lane 2: 41-49 kDa region; Lane 3: $70-100 \mathrm{kDa}$ region. Molecular mass markers (kDa) are indicated on the left

obtained due to the use of pre-stained standards when gel pieces were excised (Fig. 2).

\section{Bacterial challenge}

Challenge of rainbow trout with live Flavobacterium psychrophilum with an approximate dose of $6.25 \times 10^{6}$ cfu fish $^{-1}$ resulted in significantly different mean CPM between treatment groups (Fig. 3). Fish immunized with the 70-100 kDa region emulsified with FCA exhibited significantly $(p<0.01)$ lower mean CPM when compared to the saline controls and all other treatments (Table 1). Immunization with formalinkilled cells/FCA and the 41-49 $\mathrm{kDa}$ region/FCA also resulted in significantly $(p<0.05)$ lower mean $C P M$ when compared to the saline and saline/FCA controls, and fish immunized with the $18-28 \mathrm{kDa}$ region/FCA resulted in significantly $(p<0.05)$ lower mean CPM only when compared to the saline control. Immunization with the 70-100 $\mathrm{kDa}$ region/FCA resulted in the strongest protection with a mean RPS of $94 \%$. Mean RPS values of 58,57 , and $31 \%$ were achieved by immunization with the 41-49 kDa region/FCA, formalin-killed cells/FCA, and the $18-28 \mathrm{kDa}$ region/FCA, respectively.

At a higher challenge dose, live Flavobacterium psychrophilum at an approximate concentration of $6.25 \times$ $10^{7} \mathrm{cfu} \mathrm{fish}^{-1}$, mean CPM was higher for all treatments, but similar mortality trends were observed (Fig. 3, Table 1). Immunization with the 70-100 kDa region/ FCA, 41-49 kDa region/FCA, and formalin-killed cells/FCA resulted in significantly $(p<0.05)$ lower mean CPM when compared to the saline control. However, only fish immunized with the 70-100 kDa region/FCA and formalin-killed cells/FCA resulted in significantly $(p<0.05)$ lower mean CPM when compared to the saline/FCA control. Fish immunized with the 70-100 $\mathrm{kDa}$ region/FCA also exhibited significantly $(\mathrm{p}<0.01)$ lower mean CPM when compared to all other treatments. Mean relative percent survival values of these groups ranged from 26 to $66 \%$. At this challenge dose, fish immunized with the $18-28 \mathrm{kDa}$ region/FCA did not show significantly $(p<0.05)$ lower mean CPM than the saline controls.

Mortalities exhibited lesions typical of experimental CWD, and Flavobacterium psychrophilum was reisolated from the spleen in $86 \%(174 / 202)$ of the mortalities examined at both challenge doses. Mortality in the mock-infected controls (25 fish treatment ${ }^{-1}$ ) was negligible $(\mathrm{n}=4)$, and no $F$. psychrophilum was detected.

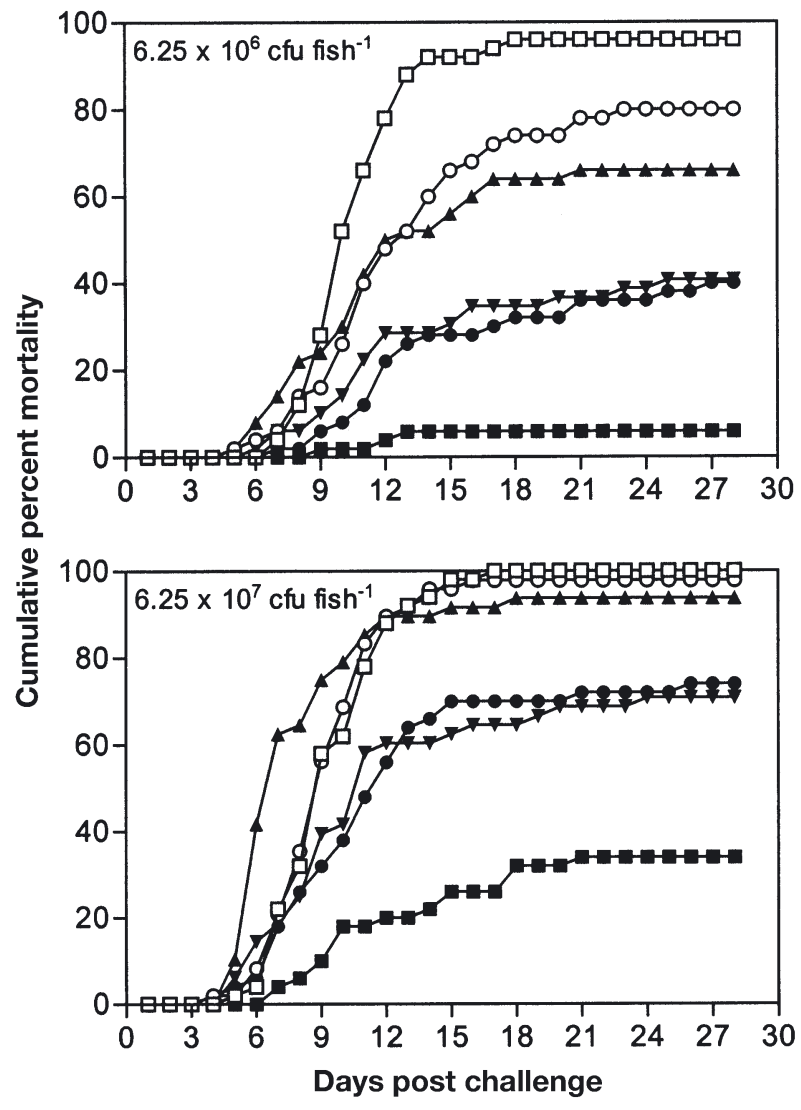

Fig. 3. Oncorhynchus mykiss. Mean cumulative percent mortality among rainbow trout (mean weight: $7.5 \mathrm{~g}$ ) after subcutaneous challenge with Flavobacterium psychrophilum (25993 ) at doses of $6.25 \times 10^{6}$ and $6.25 \times 10^{7} \mathrm{cfu}^{\mathrm{fish}}{ }^{-1}$. Fish were immunized intraperitoneally with the 70-100 $\mathrm{kDa}$ region/Freund's complete adjuvant (FCA) (匹), 41-49 kDa region/FCA $(\bullet)$, formalin-killed $F$. psychrophilum/FCA $(\mathbf{\nabla})$,

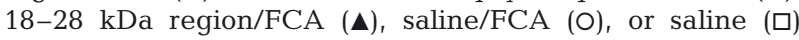


Table 1. Oncorhynchus mykiss. Mean cumulative percent mortality (CPM) and mean relative percent survival (RPS) among rainbow trout (mean weight: $7.5 \mathrm{~g}$ ) following subcutaneous challenge with Flavobacterium psychrophilum (259-93) at doses of $6.25 \times 10^{6}$ and $6.25 \times 10^{7} \mathrm{cfu}^{\text {fish }}{ }^{-1}$. Fish were immunized intraperitoneally with isolated regions of $F$. psychrophilum and a formalin-killed preparation with Freund's complete adjuvant (FCA). Mean CPM and titer values with different superscripts indicate significant differences at $\mathrm{p}<0.05$

\begin{tabular}{|lccc|}
\hline Treatment & $\begin{array}{c}\text { CPM } \pm \text { SD and } \\
\left(\text { RPS) at } 6.25 \times 10^{6}\right. \\
\text { cfu fish }\end{array}$ & $\begin{array}{c}\text { CPM } \pm \text { SD and } \\
\left(\text { RPS) at } 6.25 \times 10^{7}\right. \\
\text { cfu fish }\end{array}$ & $\begin{array}{c}\text { Average } \\
\text { titer }\end{array}$ \\
\hline $70-100 \mathrm{kDa} / \mathrm{FCA}$ & $6^{\mathrm{a}} \pm 2.6(94)$ & $34^{\mathrm{a}} \pm 2.8(66)$ & $113900^{\mathrm{a}}$ \\
$41-49 \mathrm{kDa} / \mathrm{FCA}$ & $40^{\mathrm{b}} \pm 0.0(58)$ & $74^{\mathrm{b}, \mathrm{c}} \pm 8.5(26)$ & $36200^{\mathrm{a}, \mathrm{b}}$ \\
F. psychrophilum/FCA & $41^{\mathrm{b}} \pm 8.1(57)$ & $71^{\mathrm{b}} \pm 11.8(29)$ & $84480^{\mathrm{a}}$ \\
18-28 kDa/FCA & $66^{\mathrm{c}} \pm 2.8(31)$ & $94^{\mathrm{b}, \mathrm{c}, \mathrm{d}} \pm 2.6(6)$ & $3300^{\mathrm{b}}$ \\
Saline/FCA & $80^{\mathrm{c}, \mathrm{d}} \pm 5.7(17)$ & $98^{\mathrm{c}, \mathrm{d}} \pm 3.0(2)$ & $60^{\mathrm{c}}$ \\
Saline & $96^{\mathrm{d}} \pm 0.0$ & $100^{\mathrm{d}} \pm 0.0$ & $20^{\mathrm{c}}$ \\
\hline
\end{tabular}

were identified with approximate molecular masses ranging from 16 to $60 \mathrm{kDa}$ and a fine banding pattern from 60 to $90 \mathrm{kDa}$, typical of LPS O-polysaccharide chains (Fig. 5). Serum antibodies from fish immunized with the $70-100 \mathrm{kDa}$ region reacted with multiple protein antigens with molecular masses of approximately 65 to $200 \mathrm{kDa}$ and the LPS O-polysaccharide chains at approximately 60 to 90 kDa (Figs. 4 \& 5). Fish immunized with the $41-49 \mathrm{kDa}$ region exhibited antibody specific for protein antigens with molecular masses of approximately 35, 39, and $45 \mathrm{kDa}$, and these antibodies did not react with any LPS antigens (Figs. 4 \& 5). Serum from fish immunized with the 18-28 $\mathrm{kDa}$

\section{ELISA antibody titers}

Antibody specific for Flavobacterium psychrophilum was not detected in pooled sera samples prior to immunization (titer < 100). ELISA antibody titers were detected in 5 pooled sera samples ( $\mathrm{n}=3$ fish) per treatment group prior to bacterial challenge (Table 1). Fish immunized with the 70-100 kDa region/FCA and formalin-killed cells/FCA generated highly elevated ELISA antibody titers averaging 113900 and 84480 , respectively. These responses were significantly $(\mathrm{p}<$ 0.05) different than the saline controls and all other treatments except for fish immunized with the 41-49 $\mathrm{kDa}$ region/FCA. Immunization with the 41-49 kDa region/FCA and 18-28 kDa region/FCA resulted in average ELISA antibody titers of 36200 and 3300 , respectively. These were also significantly ( $\mathrm{p}<$ 0.05) different than saline and saline/FCA controls. Control fish exhibited average ELISA antibody titers of less than 100.

\section{Western blot analysis using serum from immunized fish}

Western blot analysis performed with whole-cell lysates revealed that fish immunized with the different regions generated a specific antibody response against the respective antigens (Fig. 4). It was possible to characterize these antigens as protein or carbohydrate by comparing the western blot with whole-cell bacteria to the western blot with proteinase-K digested cells (Figs. 4 \& 5). Protein antigens were identified with apparent molecular masses of $35,39,45 \mathrm{kDa}$, and multiple protein antigens with molecular masses of approximately 65 to $200 \mathrm{kDa}$ (Fig. 4). LPS antigens region reacted primarily with LPS antigens with apparent molecular masses of approximately 16 to $60 \mathrm{kDa}$, and these antibodies exhibited faint reactivity to a few high molecular weight protein antigens (Figs. 4 \& 5). Serum antibodies from fish immunized with formalinkilled cells emulsified with FCA recognize protein antigens with apparent molecular masses of approximately 39 and $45 \mathrm{kDa}$ and numerous proteins in the 70 to $200 \mathrm{kDa}$ region (Fig. 4). Additionally, these antibodies reacted strongly with LPS antigens from 16 to

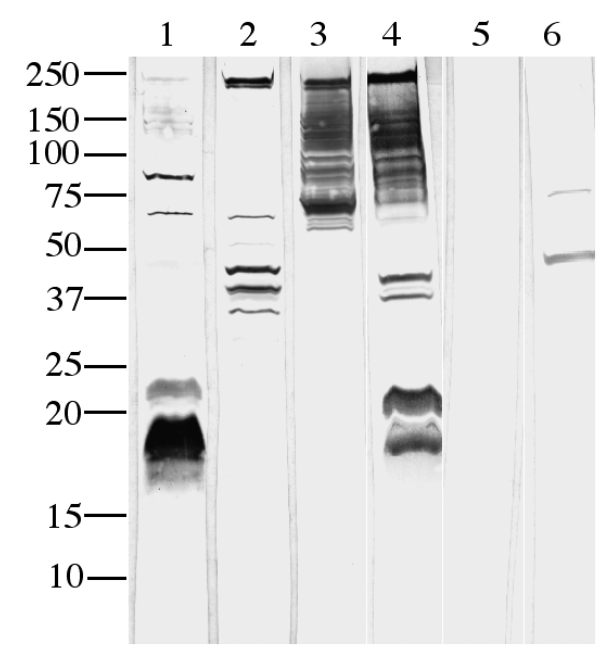

Fig. 4. Flavobacterium psychrophilum. Western blot analysis of whole-cell F. psychrophilum (259-93) lysates using Oncorhynchus mykiss sera obtained following intraperitoneal immunization with isolated regions of the bacterium and Freund's complete adjuvant (FCA) or formalin-killed F. psychrophilum emulsified with FCA. Lane 1: 18-28 kDa region/FCA; Lane 2: 41-49 $\mathrm{kDa}$ region/FCA; Lane 3: 70-100 kDa region/FCA; Lane 4: F. psychrophilum/FCA; Lane 5: saline; Lane 6: saline/FCA. Molecular mass markers $(\mathrm{kDa})$ are indicated on the left 
a

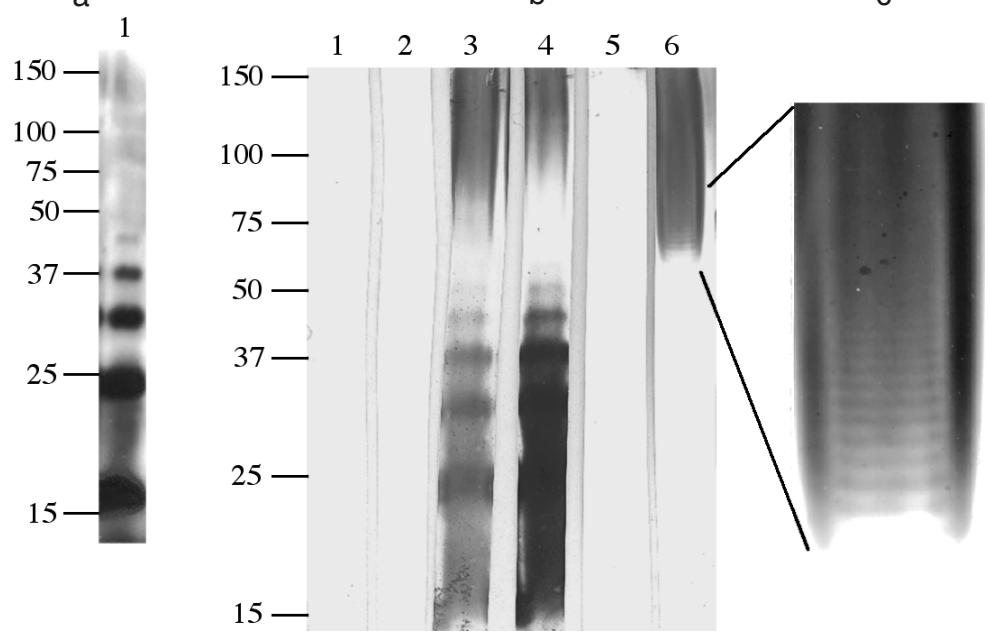

Fig. 5. Flavobacterium psychrophilum. Sodium dodecyl sulfate-polyacrylamide gel electrophoresis (SDS-PAGE) and western blot analysis of whole-cell $F$. psychrophilum (259-93) lysates digested with proteinase K. (a) Polyacrylamide gel silver-stained to visualize lipopolysaccharide (LPS) components. (b) Western blot analysis of LPS components reacted with Oncorhynchus mykiss sera obtained following intraperitoneal immunization with isolated regions of the bacterium and Freund's complete adjuvant (FCA) or formalin-killed F. psychrophilum emulsified with FCA. Lane 1: saline; Lane 2: saline/FCA; Lane 3: F. psychrophilum/FCA; Lane 4: 18-28 $\mathrm{kDa}$ region/FCA; Lane 5: 41-49 $\mathrm{kDa}$ region/FCA; and Lane 6: 70-100 kDA region/FCA. (c) Lane 6 enlarged to demonstrate the reactivity of serum antibodies to the O-polysaccharide chains of LPS. Molecular mass markers $(\mathrm{kDa})$ are indicated on the left

$60 \mathrm{kDa}$ and reacted slightly with the LPS O-polysaccharide chains at 60 to $90 \mathrm{kDa}$ (Fig. 5). Control fish injected with saline did not react with any antigens; however, fish injected with saline/FCA exhibited slight reactivity to a few high molecular weight protein antigens (Figs. 4 \& 5).

\section{DISCUSSION}

Aquaculture vaccines based on killed whole-cell preparations have proven effective for some fish pathogens (e.g. Yersinia ruckeri and Vibrio species) and licensed vaccines are available for prevention of their respective diseases. Although this represents the simplest method of vaccine production, immunization with whole-cell preparations of Flavobacterium psychrophilum has resulted in only limited success without adjuvant incorporation (Obach \& Laurencin 1991, LaFrentz et al. 2002, Rahman et al. 2002). Successful vaccine development for CWD will likely depend on identification and targeting of protective antigens.

Protective antigens of Flavobacterium psychrophilum have not been identified; however, Crump et al. (2001) characterized the antigenic composition of the bacterium. Using rabbit and convalescent rainbow trout sera, these authors identified multiple immunogenic protein antigens with molecular masses ranging from 22 to $100 \mathrm{kDa}$. A low-molecular weight LPS antigen at $16 \mathrm{kDa}$ and high molecular weight LPS Opolysaccharide chains with molecular mass of approximately 70 to $200 \mathrm{kDa}$ were also identified. The immunogenic antigens identified in the present study are similar to those characterized by Crump et al. (2001). Western blot analysis using immune serum from fish immunized with whole-cell F. psychrophilum with or without FCA revealed 3 primary immunogenic regions corresponding to approximately 18-28, 41-49, and 70-100 kDa. Since these authors worked with the same F. psychrophilum isolate (259-93), it is not surprising that similar antigens were recognized in our study.

Rahman et al. (2002) tested a vaccine for CWD in rainbow trout that was comprised of the outer membrane fraction of the bacterium. This vaccine preparation resulted in high protection with RPS values of up to $95 \%$. They concluded that the enhanced immunogenicity of the vaccine may be due to the presence of outer membrane proteins and/or LPS. Our findings support this and demonstrate that protective antigens of Flavobacterium psychrophilum are primarily within the molecular weight range of 60 to $200 \mathrm{kDa}$ and may involve LPS O-polysaccharide chains and/or proteins. A vaccine preparation comprised of high molecular weight bacterial antigens elicited near complete protection (6\% CPM, $94 \%$ RPS) in rainbow trout. Average antibody titers in fish immunized with this region were significantly elevated above controls, indicating that antibody-mediated protection was a factor in protection, which agrees with earlier observations (LaFrentz et al. 2002, 2003, Rahman et al. 2002). However, it is possible that other cellular components may have enhanced immunity and contributed to protection, as it has been speculated that such mechanisms may be involved (LaFrentz et al. 2003).

Serum antibodies from fish immunized with the $70-100 \mathrm{kDa}$ showed strong reactivity to antigens in the range of 65 to $200 \mathrm{kDa}$ by western blotting on wholecell lysates. Following proteinase K digestion, reactivity was diminished; however, a fine banding pattern typical of the repeating units of the LPS O-polysaccharide chains was apparent. LPS is known to be immunogenic in Gram-negative fish pathogens such as Aeromonas salmonicida (Hastings \& Ellis 1990, Lund et al. 1991, Aakre et al. 1994) and Vibrio species (Bøgwald et al. 
1991, Steine et al. 2001). Although A. salmonicida LPS is immunogenic, it does not appear to play a protective role (Thuvander et al. 1993, Aakre et al. 1994). Immunization with LPS from other Gram-negative bacteria has resulted in protection (Aoki et al. 1984, Salati \& Kusuda 1985, Saeed \& Plumb 1986, Baba et al. 1988, Velji et al. 1990, Soltani \& Kalbassi 2001), and this protection has been reported as antibody-mediated (Saeed \& Plumb 1986, Velji et al. 1991). Our findings suggest that the O-polysaccharide of $F$. psychrophilum may be a protective antigen, which warrants further investigation. However, a loss of antibody reactivity to a number of distinct bands in a western blot following proteinase $\mathrm{K}$ digestion of cells indicates that protein antigens in this region may also be important.

Immunization with the 41-49 and 18-28 $\mathrm{kDa}$ regions resulted in lower protection than that conferred by the 70-100 kDa region; however, these data advance our understanding of the importance of the antigens within these regions for protection from Flavobacterium psychrophilum challenge. The $41-49 \mathrm{kDa}$ region induced a protective immune response similar to formalinkilled cells emulsified with FCA. Mean relative percent survival of these treatments was 58 and $57 \%$, respectively, for the lower challenge dose $\left(6.25 \times 10^{6}\right.$ $\mathrm{cfu} \mathrm{fish}^{-1}$ ). Western blot analysis indicated that sera from fish immunized with the 41-49 $\mathrm{kDa}$ region reacted primarily with 3 protein antigens. Although near complete protection was not achieved in this treatment, the protective nature of these proteins was significant and should not be overlooked. Immunization with the 18-28 kDa region did not result in significantly different protection than the saline/FCA control; however, antibodies from these fish reacted strongly with the LPS ladder with molecular mass of 16 to $60 \mathrm{kDa}$ (Fig. 5). The reactive bands in this region represent LPS molecules with differing numbers of Opolysaccharide repeating units attached to the lipid A/core oligosaccharide, typical of smooth-type LPS (Goldman \& Leive 1980, Palva \& Mäkelä 1980, Poxton 1995). The results presented here suggest that the lipid A/core oligosaccharide component of LPS and low molecular weight protein antigens at the dose tested provide minimal protection. Similarly, Velji et al. (1992) examined the protective ability of various Vibrio ordalii LPS fractions, and concluded that fractions consisting of low molecular weight antigens $(<22 \mathrm{kDa})$ did not induce a significant protective immune response.

These results are interesting and suggest that Flavobacterium psychrophilum may have the ability to suppress or re-direct the immune system of rainbow trout in vivo. Fish immunized with killed whole-cells emulsified with FCA resulted in some protection from pathogen challenge, with a mean RPS of $57 \%$. Serum antibodies from these fish reacted with numerous high molecular weight protein antigens and reacted slightly with the O-polysaccharide of LPS, which were shown to be highly protective when administered alone. Additionally, immunization with the 18-28 kDa region resulted in a mean RPS of only $31 \%$. This was unexpected since the antigens within this region have been shown to be highly immunogenic following immunization with whole-cells (Figs. 1 \& 4). Based on these observations, it is possible that these low molecular weight antigens (consisting primarily of the lipid A/core fraction of LPS) may be involved in immunosuppression in vivo. It has been shown that protein antigens of Renibacterium salmoninarum, the causative agent of bacterial kidney disease, have the ability to suppress salmonid leucocytes (Turaga et al. 1987, Fredriksen et al. 1997) and macrophages (Siegel \& Congleton 1997) in vitro. Wood \& Kaattari (1996) reported that removal of the surface-associated $57 \mathrm{kDa}$ protein from bacterial cells by heat treatment increased immunogenicity and antigenicity of the bacterium. They speculated that removal of the $57 \mathrm{kDa}$ protein reduced the immunosuppressive ability of the cells, allowing the immune system to respond to other cell-surface antigens. Culture supernatants of Aeromonas salmonicida have also been shown to suppress the immune system of carp (Evenberg et al. 1986), and Hussain et al. (2000) identified a suppressive factor of the humoral immune response of Atlantic salmon Salmo salar to be a serine protease of $A$. salmonicida. Rahman et al. (2002) demonstrated enhanced protection to coldwater disease in rainbow trout and ayu Plecoglossus altivelis following immunization with the outer membrane fraction of $F$. psychrophilum. Such an extraction process may have removed immunosuppressive components, thus enhancing protection. In the present study, the process of isolating distinct antigenic regions of $F$. psychrophilum for immunizations may have removed immunosuppressive factors normally present in whole-cell preparations.

This is the first study to identify protective antigens isolated from Flavobacterium psychrophilum. Future studies should further characterize specific antigens involved in protection that may serve as vaccine target antigens. Should such targets be identified, it will be necessary to investigate the effectiveness of different routes of vaccine delivery and determine whether there is cross-protection against a range of F. psychrophilum isolates.

Acknowledgements. The authors thank A. Morton and A. Weighall of Clear Springs Foods for significant contributions and assistance. Funding for this project was provided in part through the US Department of Agriculture (SBIR Phase I Agreement No. 2001-33610-10373), the WSU/UI Center for Reproductive Biology (USFWS Agreement No. 10140-1-G0019A), and the University of Idaho Research Council seed grant. 


\section{LITERATURE CITED}

Aakre R, Wergeland HI, Aasjord PM, Endresen C (1994) Enhanced antibody response in Atlantic salmon (Salmo salar L.) to Aeromonas salmonicida cell wall antigens using a bacterin containing $\beta$-1,3-M-glucan as adjuvant. Fish Shellfish Immunol 4:47-61

Aoki T, Sakai M, Takahashi S (1984) Protective immunity in ayu, Plecoglossus altivelis, vaccinated by immersion with Vibro anguillarum. Fish Pathol 19:181-185

Ausubel FM, Brent R, Kingston RE, Moore DD, Seidman JG, Smith JA, Struhl K (1999) Short protocols in molecular biology: a compendium of methods from current protocols in molecular biology, 4th edn. John Wiley \& Sons, New York

Baba T, Imamura J, Izawa K (1988) Immune protection in carp, Cyprinus carpio L., after immunization with Aeromonas hydrophila crude lipopolysaccharide. J Fish Dis 11: $237-244$

Bøgwald J, Stensvåg K, Hoffman J, Jørgensen T (1991) Antibody specificities in Atlantic salmon, Salmo salar L., against the fish pathogens Vibrio salmonicida and Vibro anguillarum. J Fish Dis 14:79-87

Crump EM, Perry MB, Clouthier SC, Kay WW (2001) Antigenic characterization of the fish pathogen Flavobacterium psychrophilum. Appl Environ Microbiol 67: $750-759$

DeLuca D, Wilson M, Warr GW (1983) Lymphocyte heterogeneity in the trout, Salmo gairdneri, defined with monoclonal antibodies to IgM. Eur J Immunol 13:546-551

Evenberg D, de Graaff P, Fleuren W, van Muiswinkel WB (1986) Blood changes in carp (Cyprinus carpio) induced by ulcerative Aeromonas salmonicida infections. Vet Immunol Immunopathol 12:321-330

Fredriksen A, Endresen C, Wergeland HI (1997) Immunosuppressive effect of a low molecular weight surface protein from Renibacterium salmoninarum on lymphocytes from Atlantic salmon (Salmo salar L.). Fish Shellfish Immunol 7: 273-282

Goldman R, Leive L (1980) Heterogeneity of antigenic-side chain length in lipopolysaccharide from Escherichia coli O111 and Salmonella typhimurium LT2. Eur J Biochem 107:145-153

Hastings TS, Ellis AE (1990) Detection of antibodies induced in rainbow trout by different Aeromonas salmonicida vaccine preparations. J Aquat Anim Health 2:135-140

Hitchcock PJ, Brown TM (1983) Morphological heterogeneity among Salmonella lipopolysaccharide chemotypes in silver-stained polyacrylamide gels. J Bacteriol 154:269-277

Holt RA (1987) Cytophaga psychrophila, the causative agent of bacterial cold-water disease in salmonid fish. $\mathrm{PhD}$ dissertation, Oregon State University, Corvallis, OR

Holt RA, Rohovec JS, Fryer JL (1993) Bacterial coldwater disease. In: Inglis V, Roberts RJ, Bromage NR (eds) Bacterial diseases of fish. Blackwell Scientific Publications, Oxford, p 3-23

Hussain I, Mackie C, Cox D, Alderson R, Birkbeck TH (2000) Suppression of the humoral immune response of Atlantic salmon, Salmo salar L., by the $64 \mathrm{kDa}$ serine protease of Aeromonas salmonicida. Fish Shellfish Immunol 10: 359-373

Laemmli UK (1970) Cleavage of structural proteins during the assembly of the head of bacteriophage T4. Nature 227: $680-685$

LaFrentz BR, LaPatra SE, Jones GR, Congleton JL, Sun B, Cain KD (2002) Characterization of serum and mucosal antibody responses and relative percent survival in rain- bow trout (Oncorhynchus mykiss) following immunization and challenge with Flavobacterium psychrophilum. J Fish Dis 25:703-713

LaFrentz BR, LaPatra SE, Jones GR, Cain KD (2003) Passive immunization of rainbow trout, Oncorhynchus mykiss (Walbaum), against Flavobacterium psychrophilum, the causative agent of bacterial coldwater disease and rainbow trout fry syndrome. J Fish Dis 26:377-384

Lehmann J, Mock D, Stürenberg FJ, Bernardet JF (1991) First isolation of Cytophaga psychrophila from a systemic disease in eel and cyprinids. Dis Aquat Org 10:217-220

Lund V, Jørgensen T, Holm KO, Eggset G (1991) Humoral immune response in Atlantic salmon, Salmo salar L., to cellular and extracellular antigens of Aeromonas salmonicida. J Fish Dis 14:443-452

Merle C, Faure D, Urdaci MC, Le Hénaff M (2003) Purification and characterization of a membrane glycoprotein from the fish pathogen Flavobacterium psychrophilum. J Appl Microbiol 94:1120-1127

Michel C, Antonio D, Hedrick RP (1999) Production of viable cultures of Flavobacterium psychrophilum: approach and control. Res Microbiol 150:351-358

Obach A, Laurencin FB (1991) Vaccination of rainbow trout Oncorhynchus mykiss against the visceral form of coldwater disease. Dis Aquat Org 12:13-15

Palva T, Mäkelä H (1980) Lipopolysaccharide heterogeneity in Salmonella typhimurium analyzed by sodium dodecyl sulfate/polyacrylamide gel electrophoresis. Eur J Biochem 107:137-143

Poxton IR (1995) Antibodies to lipopolysaccharide. J Immunol Methods 186:1-15

Rahman MH, Kuroda A, Dijkstra JM, Kiryu I, Nakanishi T, Ototake M (2002) The outer membrane fraction of Flavobacterium psychrophilum induces protective immunity in rainbow trout and ayu. Fish Shellfish Immunol 12 169-179

Saeed MO, Plumb JA (1986) Immune response of channel catfish to lipopolysaccharide and whole cell Edwardsiella ictaluri vaccines. Dis Aquat Org 2:21-25

Salati F, Kusuda R (1985) Vaccine preparations used for immunization of eel Anguilla japonica against Edwardsiella tarda infection. Bull Jpn Soc Sci Fish 51:1233-1237

Siegel DC, Congleton JL (1997) Bactericidal activity of juvenile chinook salmon macrophages against Aeromonas salmonicida after exposure to live or heat-killed Renibacterium salmoninarum or to soluble proteins produced by R. salmoninarum. J Aquat Anim Health 9:180-189

Soltani M, Kalbassi MR (2001) Protection of persian sturgeon (Acipenser persicus) fingerling against Aeromonas hydrophila septicemia using three different antigens. Bull Eur Assoc Fish Pathol 21:235-240

Steine NO, Melingen GO, Wergeland HI (2001) Antibodies against Vibrio salmonicida lipopolysaccharide (LPS) and whole bacteria in sera from Atlantic salmon (Salmo salar L.) vaccinated during the smolting and early post-smolt period. Fish Shellfish Immunol 11:39-52

Thuvander A, Wichardt UP, Reitan LJ (1993) Humoral antibody response of brown trout (Salmo trutta) vaccinated against furunculosis. Dis Aquat Org 17:17-23

Towbin H, Staehelin T, Gordon J (1979) Electrophoretic transfer of proteins from polyacrylamide gels to nitrocellulose sheets: procedure and some applications. Proc Natl Acad Sci USA 76:4350-4354

Turaga P, Wiens G, Kaattari S (1987) Bacterial kidney disease: the potential role of soluble protein antigen(s). J Fish Biol 31(Suppl A):191-194

Velji MI, Albright LJ, Evelyn TPT (1990) Protective immunity in 
juvenile coho salmon (Oncorhynchus kisutch) following immunization with Vibrio ordalii lipopolysaccharide or from exposure to live $V$. ordalii cells. Dis Aquat Org 9:25-29

Velji MI, Evelyn TPT, Albright LJ (1991) Nature of the immune response in coho salmon Oncorhynchus kisutch following vaccination with Vibrio ordalii lipopolysaccharide by two different routes. Dis Aquat Org 11:79-84

Velji MI, Albright LJ, Evelyn TPT (1992) Immunogenicity of

Editorial responsibility: David Bruno,

Aberdeen, UK various Vibro ordalii lipopolysaccharide fractions in coho salmon Oncorhynchus kisutch. Dis Aquat Org 12:97-101 Wood EM, Yasutake WT (1956) Histopathology of fish III. Peduncle ('coldwater') disease. Prog Fish Cult 18:58-61

Wood PA, Kaattari SL (1996) Enhanced immunogenicity of Renibacterium salmoninarum in chinook salmon after removal of the bacterial surface-associated $57 \mathrm{kDa}$ protein. Dis Aquat Org 25:71-79

Submitted: October 30, 2003; Accepted: February 12, 2004 Proofs received from author(s): April 10, 2004 